\title{
DETEKSI IgM ANTI Salmonella Enterica Serovar Typhi DENGAN PEMERIKSAAN TUBEX TF DAN TYPHIDOT-M
}

\author{
Ilham*1, Jusak Nugraha ${ }^{2}$, Marijam Purwanta ${ }^{3}$ \\ Program Studi S2 Imunologi, Sekolah Pascasarjana Universitas Airlangga, Surabaya \\ e-mail: *1 ilham.ku31@gmail.com, ${ }^{2}$ jusak.nugraha@yahoo.com, \\ ․ㅡㄹㅏijampurwanta@yahoo.com
}

\begin{abstract}
Abstrak
Bakteri Salmonella enterica Serovar Typhi merupakan bakteri Gram-negatif yang bersifat patogen fakultatif intraseluler, masuk ke dalam tubuh manusia dan menyebabkan penyakit infeksi sistemik akut yang disebut demam tifoid. Deteksi dini antibodi anti Salmonella enterica Serovar Typhi masih merupakan tantangan dalam penegakan diagnosis laboratorium demam tifoid.

Tujuan penelitian ini untuk mengidentifikasi perbedaan antara hasil deteksi kit TUBEX TF dan Typhidot-M pada pemeriksaan IgM anti Salmonella enterica Serovar Typhi pasien demam tifoid, menganalisis hubungan suhu tubuh dengan hasil pemeriksaan TUBEX $T F$, menganalisis hubungan suhu tubuh dengan hasil pemeriksaan Typhidot-M dan menganalisi tingkat kesesuaian hasil deteksi IgM dengan pemeriksaan TUBEX TF dengan Typhidot-M.

Penelitian ini merupakan penelitian deskriptif dengan pendekatan observasional, tiga puluh delapan sampel yang berasal dari pasien demam tifoid di RSUD Dr. Soetomo Surabaya.

Hasil penelitian ini bahwa kit TUBEX TF menujukkan hasil (65.8\%) positif dan (34.2\%) negatif. Sedangkan kit Kit Typhidot-M menunjukkan (60.5\%) positif dan 15 (39.5\%) sampel negatif. Analisis statistik menunjukkan hasil nilai kappa: 0.887>0.75, kedua kit terdapat kesesuaian dengan tingkat kesesuaian sangat baik.

Berdasarkan hasil penelitian ini disarankan kit Typhidot-M dapat digunakan sebagai diagnosis cepat bila kit TUBEX TF tidak tersedia. Untuk peneliti selanjutnya disarankan untuk membandingkan hasil TUBEX TF dan Typhodot-M dengan menggunakan kultur darah sebagai diagnosis gold standar untuk deteksi IgM anti Salmonella enterica Serovar Typhi.
\end{abstract}

Kata Kunci: IgM, Salmonella enterica Serovar Typhi, TUBEX TF, Typhidot-M

\begin{abstract}
Salmonella enterica Serovar Typhi is a Gram-negative enteric bacteria, it is a facultative intracellular pathogen that causes typhoid fever. Rapid detection of antiSalmonella enterica Serovar Typhi antibodies remain challenge in diagnosis of typhoid fever.

The purpose of this research were to identify the difference result of TUBEX TF and Typhidot-M in detecting typhoid fever; to analyze correlation between the degree of body temperature and the result of IgM detected by TUBEX TF; to analyze correlation between the degree of body temperature and the result of IgM detected by Typhidot-M; and to analyze the conformity between the result of TUBEX TF with the result of Typhdot-M in detecting IgM anti-Salmonella enterica Serovar Typhi from typhoid fever patients.

This study is a descriptive observational approach design. Thirty-eight serum samples ware taken from regional general hospital Dr. Soetomo Surabaya.
\end{abstract}


The result of TUBEX TF kit showed that 25 (65.8\%) samples were positive and 13 (34.2\%) samples were negative. While the reasult of Typhidot-M kit showed that 23 (60.5\%) samples were positive and 15 (39.5\%) samples were negative. Statistically analysis showed that TUBEX TF and Typhidot-M test had a very good conformity level by Kappa value 0.887> (0.75).

Based on the results of this research then it was suggested that Typhidot-M kit could be used as a rapid diagnosis whenever the TUBEX TF kit was not available. For further research, it is advisable to compare the results of TUBEX TF and Typhodot-M by using blood cultures as a gold standard to detect IgM anti-Salmonella enterica Serovar Typhi (S. typhi).

Keyword: IgM, Salmonella enterica Serovar Typhi, TUBEX TF, Typhidot-M 


\section{PENDAHULUAN}

Demam tifoid merupakan suatu penyakit sistemik akut yang disebabkan oleh bakteri Salmonella enterica serovar Typhi (S. typhi), yaitu suatu bakteri Gram-negatif enterik (Enterobaeteriaceae) yang bersifat patogen fakultatif intraseluler (Jawetz et al., 1996; Mweu et al., 2008; Kaur et al., 2012).

Salmonella merupakan agen penyebab penyakit salmonellosis. Bakteri ini termasuk ke dalam famili Enterobacteriaceae, berbentuk batang, berflagella (Pui et al., 2011), termasuk dalam golongan bakteri Gram-negatif, dan bersifat anaerob fakultatif. Bakteri dari golongan Salmonella ini mampu menyerang hewan dan manusia dengan berbagai tingkat infeksi yang bervariasi, mulai infeksi ringan yang mengakibatkan diare sampai pada infeksi berat, misalnya demam tifoid (Diepen et al., 2005).

Penyakit ini masih merupakan masalah kesehatan yang utama di dunia. Lazim di tentukan di berbagai belahan dunia yang memiliki keterbatasan akses ke sarana air bersih dan kurangnya sanitasi, seperti di India, Nepal, Pakistan, (Crump et al., 2010). Estimasi global terbaru penyakit ini berkisar dari 21 juta kasus per tahun dan 222.000 kematian per tahun di seluruh dunia (World Health Organization, 2014). Negara-negara yang memiliki insidensi tinggi (100/100.000 populasi per tahun) terletak di Asia Tenggara dan Asia bagian selatan serta di area pulau-pulau Pasifik (Crump et al., 2004; Merieux, 2007). Di Indonesia, insidensi penyakit demam tifoid tidak diketahui secara pasti, diperkirakan terdapat 900.000 kasus dan 20.000 kematian di seluruh Nusantara per tahun (World Health Organization, 2003; Merieux, 2007).

Penegakan diagnosis demam tifoid hanya dengan melihat tanda-tanda klinis sulit dilakukan karena tidak spesifiknya tanda-tanda dan gejala yang timbul, Gejala klinis demam tifoid yang timbul pada minggu pertama sakit yaitu keluhan demam, nyeri kepala, malaise dan gangguan gastrointestinal (Sudoyo, 2009). Adapun kategori suhu tubuh untuk mengetahui keluhan demam terdiri dari: (1). Hipotermi bila suhu tubuh kurang dari $36^{\circ} \mathrm{C}$, (2). Normal bila suhu tubuh berkisar antara 360C sampai dengan $37,5^{\circ} \mathrm{C}$, (3). Febris/pireksia/demam bila suhu tubuh antara $37,5^{\circ} \mathrm{C}$ sampai dengan $40^{\circ} \mathrm{C}$, (4). Hipertermi, bila suhu tubuh lebih dari $40^{\circ} \mathrm{C}$ (Tamsuri, 2007).

Studi yang dilakukan di Tanzania menggunakan suhu $>38^{\circ} \mathrm{C}$ (riwayat demam atau menunjukkan pireksia) sebagai kreteria inklusi untuk melakukan evaluasi kit TUBEX
TF dan Typhidot-M yang dibandingkan dengan 
hasil kultur darah menunjukkah hasil hubungan antara kit diagnosis cepat pada demam tifoid buruk (keddy et al., 2011).

Berbagai metode diagnostik sebagai pengganti pemeriksaan Widal dan kultur darah sebagai metode konvensional masih memerlukan penelitian lebih lanjut. Beberapa metode diagnostik yang lebih cepat, mudah dilakukan dan terjangkau harganya untuk negara berkembang dengan sensitivitas dan spesifisitas yang cukup baik, seperti pemeriksaan TUBEX

TF, Typhidot dan Dipstik mulai dapat dikembangkan penggunaannya di Indonesia (Tumbelaka, 2003).

TUBEX® TF merupakan suatu rapid test in vitro dengan metode inhibition magnetlc binding immunoasay (IMBI) yang dapat mendeteksi IgM yang spesifik terhadap antigen O9 Salmonella enterica Serovar Typhi yang terdapat dalam serum penderita. Interpretasi dari hasil pemeriksaan ini bersifat semikuantitatif yaitu dengan membandingkan warna yang timbul pada hasil reaksi pemeriksaan dengan wama standar yang memiliki skor yang terdapat pada kit TUBEX® TF (Pacific Biotek indoIntralab, 2007).

Pemeriksaan serologis Typhidot merupakan suatu pemeriksaan serologi yang didasarkan pada deteksi antibodi spesifik IgM

maupun IgG terhadap Salmonella enterica Serovar Typhi. Pemeriksaan menggunakan suatu membran nitroselulosa yang diisi $50-\mathrm{kDa}$ spesifik protein dan antigen kontrol. Deteksi

antibodi IgM menunjukkan tahap awal infeksi pada demam tifoid akut sedangkan adanya peningkatan IgG menandakan infeksi yang lebih lanjut. Pada Typhidot-M yang merupakan modifikasi dari metode Typhidot telah dilakukan inaktivasi dari IgG total sehingga menghilangkan pengikatan kompetitif dan

memungkinkan pengikatan antigen terhadap IgM spesifik. Walaupun kultur merupakan pemeriksaan gold standar, perbandingan kepekaan Typhidot-M dan metode kultur adalah

$>93 \%$. Typhidot-M sangat bermanfaat untuk diagnosis cepat di daerah endemis demam tifoid (Marleni, 2012; WHO, 2003). Hasil positif pada pemeriksaan Typhidot didapatkan 2-3 hari setelah infeksi dan dapat mengidentifikasi secara spesifik antibodi IgM dan IgG terhadap antigen Salmonella enterica Serovar Typhi seberat 50$\mathrm{kDa}$ yang terdapat pada strip nitroselulosa (Sudoyo, 2009).

\subsection{Tujuan Khusus}

1. Mengidentifikasi perbedaan hasil interpretasi antara pemeriksaan TUBEX $^{\circledR} T F$ dan Typhidot-M anti-Salmonella enterica 
serovar Typhi pada serum pasien demam tifoid di RSUD Dr. Soetomo Surabaya.

2. Menganalisis tingkat kesesuaian hasil pemeriksaan kit TUBEX ${ }^{\circledR} T F$ dan Typhidot$\mathrm{M}$ anti-Salmonella enterica serovar Typhi pada serum pasien demam tifoid di RSUD Dr. Soetomo surabya.

3. Menganalisis hubungan suhu tubuh dengan hasil deteksi kit TUBEX $^{\circledR} T F$ dalam pemeriksaan anti-Salmonella enterica serovar Typhi pada serum pasien demam tifoid di RSUD Dr. Soetomo surabya.

4. Menganalisis hubungan suhu tubuh dengan hasil deteksi kit Typhidot-M dalam pemeriksaan anti-Salmonella enterica serovar Typhi pada serum pasien demam tifoid di RSUD Dr. Soetomo surabya.

\section{TINJAUAN PUSTAKA}

2.1 Demam tifoid

Penyakit demam tifoid merupakan suatu penyakit sistemik akut yang disebabkan oleh infeksi bakteri Salmonella enterica serovar Typhi (Nasronuddin, 2007). Bakteri ini merupakan patogen intra seluler fakultatif dan hanya menyebabkan penyakit demam tifoid pada manusia sampai saat ini (Mweu et al., 2008; Kaur et al., 2012).

Terdapat berbagai macam faktor yang mempengaruhi kejadian demam tifoid, diantaranya yaitu: kurangnya kebersihan individu, lingkungan tempat tinggal yang sangat padat, persediaan air bersih yang belum mencukupi, menurunnya system imun penderita, adanya mutasi genetik bakteri Salmonella enterica serovar Typhi dan munculnya multidrug resistant (Kumar et al., 2007; Nasronuddin, 2007; Kothari et al., 2008; Zaki et al., 2011).

2.2. Salmonella enterica serovar Typhi ( $S$. typhi)

2.2.1. Klasifikasi Salmonella enterica serovar Typhi (S. typhi)

Klasifikasi Salmonella enterica serovar Typhi sebagai berikut:

Kingdom: Bacteria

Phylum: Proteobacteria

Class: Proteobacteria Ordo:

Enterobacteriales Family:

Enterobacteriaceae Genus:

Salmonella

Species: Salmonella enteric

Subspesies: Enterica

Serovar: Typhi

Serovar merupakan klasifikasi

Salmonella ke subspesies berdasarkan antigen organisme yang menyajikan. Hal ini berdasarkan pada skema klasifikasi Kauffman- 
White yang membedakan varietas serologis satu dengan lainnya. Serovar biasanya dimasukkan ke dalam kelompok subspesies setelah genus dan spesies, dengan serovar dikapitalisasi, tidak dicetak miring: Contohnya Salmonella enterica serovar Typhimurium (Achtman et al., 2012).

Menurut Kauffman-White sceme bahwa berdasarkan identifikasi serologis Salmonella enterica Serovar Typhi dapat dikelompokkan ke dalam serovar berdasarkan formula perbedaan antigen, yaitu berdasarkan antigen $\mathrm{O}$ (somatik), antigen $\mathrm{Vi}$ (kapsul) dan antigen $\mathrm{H}$ (flagella) (Holt et al.,1994). Saat ini system penamaan serotype/serovar digunakan Centers for Disease Control and Prevention (CDC) dan WHO Collaborating Centre (Brenner et al., 2000).

Salmonella enterica serovar Typhi merupakan organisme yang sangat klonal, bakteri ini memiliki variasi genom yang terbatas, yang mana hal ini menunjukan bahwa bakteri ini belum lama berevolusi (Roumagnac et al., 2006). Banyak gen yang berhubungan dengan intestinal persistence misalnya $s h d A, r a t B$ atau yang berhubungan dengan interaksi dengan permukaan tubuh host, misalnya fimbriae, pili, dan lainnya mengalami inaktivasi (Holt et al., 2009). Sebagai contoh gen-gen yang berkontribusi atas pelepasan cairan, misalnya sopA atau daya tahan di lingkungan intra seluler, misalnya sopE2, sseJ mengalami inaktivasi (McClelland et al., 2004; Holt et al., 2009). Akibatnya, Salmonella enterica serovar Typhi yang menginvasi akan melwati jalur/siklus hidup yang sederhana dan berefek terhadap terbatasnya aktivasi respon inflamasi host (McClelland et al., 2004; Holt et al., 2009).

Outer membrane protein (OMP) merupakan dinding sel terluar membran sitoplasma dan lapisan peptidoglikan yang berfungsi sebagai sawar untuk mengendalikan aktivitas masuknya cairan ke dalam membran sitoplasma serta berfungsi sebagai reseptor bakteriofag dan bakteriolisin (Marleni, 2012).

\subsection{Imunopatogenesis demam tifoid}

Patogenesis demam tifoid bersifat kompleks, berbagai komponen patogen Salmonella enterica serovar Typhi bekerja secara serasi pada saat interaksi dengan host (Nasronuddin, 2007). Dosis infeksius Salmonella enterica serovar Typhi bervariasi antara 1000 hingga 1 juta organisme (Hornick et al., 1970). Salmonella enterica serovar Typhi masuk ke dalam tubuh melalui makanan atau minuman yang tercemar menuju lambung, dan yang berhasil melewati lambung akan mencapai usus halus (Nasronuddin, 2007; Kaur et al., 2012). 
Salmonella enterica serovar Typhi masuk ke dalam tubuh melalui makanan atau minuman yang tercemar menuju lambung, dan yang berhasil melewati lambung akan mencapai usus halus (Monack et al., 2004). Sel-sel fagosit yang terinfeksi akan terorganisir ke dalam foci khusus ysng akan menjadi lesi patologis yang di kelilingi oleh jaringan normal (Monack et al., 2004; Kaur et al., 2012). Pembentukan lesi merupakan suatu proses dinamis yang membutuhkan berbagai molekul adhesi seperti ICAM-1 (intraceluler adhesion molecule-1), VCAM-1 (vascular cell adhesion molecule-1), serta kinerja sitokin-sitokin yang berimbang, seperti: Tumor Nekrosis Factor (TNF), interleukin (IL) -12, IL-8, IL-14, IL-15 dan interferon gamma (IFN- $\gamma$ ) (Kaur et al., 2012). Sel dendritik berperan dalam mempresentasikan antigen bakteri sel-sel imun yang akan membangkitkan aktivasi limfosit $\mathrm{T}$ dan limfosit B (Kaur et al., 2012). Sel limfosit T dan limfosit B akan keluar dari nodul limfatik dan mencapai hati dan limpa melalui jaringan RES (reticuloendotelial system) (House et al., 2001; Nasronuddin, 2007). Di organ-organ ini bakteri akan dibunuh terutama oleh makrofag. Namun bagaimanapun Salmonella enterica serovar Typhi merupakan organisme intraseluler fakultatif yang mampu bertahan hidup dan bermultipikasi di dalam sel fagosit (House et al., 2001; Kaur et al., 2012).

Pada ambang batas tertentu, yang di tentukan oleh jumlah bakteri, virulensi bakteri dan respon imun host, bakteri Salmonella enterica serovar Typhi akan keluar dari habitat intraseluler mereka menuju aliran darah (Kaur $e t$ al., 2012). Fase bakterimia dari penyakit demam tifoid di tandai oleh menyebarnya bakteri Salmonella enterica serovar Typhi (Kaur et al., 2012). Lokasi infeksi sekunder yang paling sering adalah hati, limpa, sumsum tulang, kandung empedu, dan peyer's patches di ileum terminal. Di hati, Salmonella enterica serovar Typhi menimbulkan aktivasi sel kupfer yang memiliki daya mikrobisidal yang tinggi dan dapat menetralisir bakteri dengan menggunakan oxidative free radicals, nitric oxide serta enzimenzim (Kaur et al., 2012). Bakteri yang berhasil bertahan hidup akan menginvasi hepatosit dan menyebabkan kematian seluler, utamanya melalui mekanisme apoptosis (Kaur et al., 2012).

\subsection{Respon imun terhadap infeksi salmonella enterica serovar typhi}

Respon imun host pada infeksi Salmonella enterica serovar Typhi melibatkan innate immunity dan adaptive immunity
(Humoral dan Seluler) (Kaur et al., 2012). Sel- 
Jurnal Biosains Pascasarjana Vol. 19 (2017) pp

(C) (2017) Sekolah Pascasarjana Universitas Airlangga, Indonesia

sel inflamasi ini memproduksi sitokin seperti TNF- $\alpha$, IFN- $\gamma$, IL-1, IL-2, IL-6, dan IL-8. TNF$\alpha$ memiliki aktifitas antibacterial yang sangat banyak terhadap Salmonella typhi, dan sel-sel kuffer merupakan penghasil utama TNF- $\alpha$ di hati (Santos S.A et al., 2011). Clearance bakteri Salmonella enterica serovar Typhi jaringan memerlukan aktivasi $\mathrm{CD}^{+}, \mathrm{T}$ cell reseptor (TCR)- $\alpha \beta$ dari sel $\mathrm{T}$, dan dikontrol oleh gen Major Histocompatibility Complex (MHC) kelas II (McSorley et al., 2000; Kaur et al., 2012).

Salmonella enterica serovar Typhi yang berada di intrasel tidak dapat diserang oleh imunitas humoral dan komplemen, sehingga diperlukan respon imun seluler untuk mengatasinya. Untuk itu, dalam hal ini antibodi berperan untuk meningkatkan aktifitas makrofag dan menghambat perlekatan dengan reseptor sel. IgM berfungsi untuk netralisasi, sedangkan IgG berfungsi untuk meningkatkan fagositosis dan aktivasi komplemen (Nasronuddin, 2007).

Gambar 2.2 patogenesis infeksi salmonella enterica serovar typhi pada manusia (Kaur et al., 2012)

Salmonella enterica serovar Typhi pada manusia: bakteri memasuki payers patches dari permukaan mukosa saluran usus dengan mengivasi sel $M$, sel epitel spesifk yang menangkap dan membawa antigen ke luminal untuk di tangkap oleh sel fagosit. Hal ini diikuti oleh inflamasi dan fagositosis bakteri oleh neutrophil, makrofag dan pembentukan sel $\mathrm{T}$ dan B.

Bakteri dapat bertahan di mesenteric lymph nodes (MLNs), sumsum tulang dan kantung empedu seumur hidup, dan terjadi pembelahan secara berkala pada permukaan mukosa melalui saluran empedu dan/atau mesenteric lymph nodes (MLNs) dari usus kecil , dan penumpahan dapat terjadi dari permukaan mukosa. Interferon (IFN- $\gamma$ ), yang dapat disekresi oleh sel $\mathrm{T}$, memiliki peran dalam mengendalikan replikasi Salmonella intraselular. Interleukin (IL) -12, yang dapat meningkatkan produksi (IFN- $\gamma$ ) dan sitokin tumor-necrosis

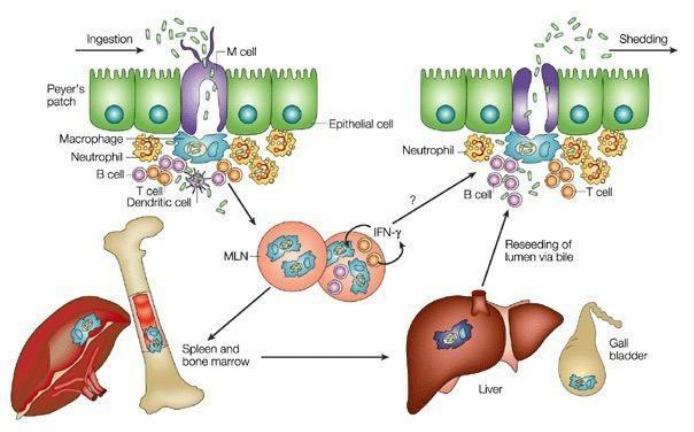

produki (IFN) din sitokin tumor-necrosis 
factor $\left(\mathrm{TNF}^{\alpha} \boldsymbol{\alpha}\right)$ juga berkontribusi terhadap pengendalian pertahanan Salmonella (Kaur et al., 2012)

\subsection{Gejala klinis demam tifoid}

Gejala klinis demam tifoid pada anak biasanya lebih ringan jika dibanding dengan penderita dewasa. Masa inkubasi demam tifoid 3 sampai 60 hari dengan rata-rata antara 10 sampai 14 hari (Nelwan, 2007). Manifestasi klinis demam tifoid seringkali tidak khas dan sangat bervariasi dari gejala ringan seperti demam yang tidak terlalu tinggi, malaise dan batuk kering. sesuai dengan patogenesis demam tifoid sampai dengan bentuk klinis yang berat baik berupa gejala sistemik panas tinggi, gejala septik yang lain, ensefalopati atau timbul komplikasi gastrointestinal berupa perforasi usus atau perdarahan. Hal ini menyebabkan sulit untuk melakukan penegakan diagnosis berdasarkan gambaran klinisnya saja (Darmowandoyo, 2003; Tumbelaka, 2003).

\subsection{Skor Nelwan}

Skor nelwan merupakan skala penilaian klinis demam tifoid diaman skor terdiri dari nilai skor minimal yaitu 1 dan nilai skor maksimal 20, semakin tinggi skor semakin mendukung demam tifoid. Penilaian klinis demam tifoid bila terdapat nilai skor $\geq 8$. Diagnosis bisa ditegakkan melalui tanda-tanda klinis, terutama lima tanda utama (mual, nyeri abdominal, anoreksia, muntah dan gangguan motilitas saluran cerna) dan kriteria lainnya. Berdasarkan tanda-tanda klinis, bisa didapatkan skor klinik (kalbemed, 2014).

\subsection{Klasisifikasi batas normal suhu tubuh manusisa}

International Union of Physiological Sciences Commission for Thermal Physiology mendefinisikan demam/febris sebagai suatu keadaan peningkatan suhu inti, yang sering merupakan bagian dari respons pertahanan organisme multiselular (host) terhadap invasi mikroorganisme atau benda mati yang patogenik atau dianggap asing oleh host. ElRahdi dkk., mendefinisikan demam (pireksia) dari segi patofisiologis dan klinis.

Pirogen eksogen biasanya merangsang demam dalam 2 jam setelah terpapar. Umumnya, pirogen berinteraksi dengan sel fagosit, makrofag atau monosit, untuk merangsang sintesis IL-1. Mekanisme lain yang mungkin berperan sebagai pirogen eksogen (misalnya endotoksin) bekerja langsung pada hipotalamus untuk mengubah pengatur suhu. Pirogenitas bakteri Gram-negatif (misalnya
Escherichi coli, Salmonela) disebabkan adanya lzeat-stable factor yaitu endoktosin, suatu pirogen eksogen yang pertama kali ditemukan. Komponen aktif endotoksin berupa lapisan luar bakteri yaitu lipopolisakarida (Soedarmo et al., 2008).

Suhu tubuh dibagi menjadi: (1). Hipotermi bila suhu tubuh kurang dari $36^{\circ} \mathrm{C}$, (2). Normal bila suhu tubuh berkisar antara 360C sampai dengan $37,5^{\circ} \mathrm{C}$, (3). Febris/pireksia/demam bila suhu tubuh antara $37,6^{\circ} \mathrm{C}$ sampai dengan $40^{\circ} \mathrm{C}$, (4). Hipertermi, bila suhu tubuh lebih dari $40^{\circ} \mathrm{C}$ (Tamsuri, 2007).

\subsection{Imunoglobulin M (IgM)}

Immunoglobulin M (IgM) merupakan suatu protein dengan berat molekul yang tinggi (makroglobulin), dalam bentuk tersekresi antibodi ini dapat terdiri atas 5 atau 6 (jarang) subunit (IgM monomer; pentamer heksamer (Abbas et al., 2012). Setiap monomer IgM terdiri atas dua heavy chain dan dua light chain yang terhubung melalui suatu struktur polipeptida $15-\mathrm{kDa}$ (ikatan disulfida) yang disebut joining $(J)$ chain. IgM memiliki konsentrasi serum sebesar $1,5 \mathrm{mg} / \mathrm{mL}$, dan serum half life selama 5 hari (Abbas et al., 2012). Imunoglobulin $M$ ( $\operatorname{IgM})$ merupakan imunoglobulin yang pertama kali disintesis oleh neonatus, dan merupakan kelas imunoglobulin yang paling berpengaruh pada tahap awal respon imun.

Imunoglobulin heavy chain dan light chain disintesis di membrane-bound ribosom pada retikulum endoplasma kasar, yang kemudian akan ditranslokasikan ke retikulum endoplasma, imunoglobulin heavy chain akan mengalami $\mathrm{N}$-glycosylated selama proses translokasi ini (Abbas et al., 2012). Proses folding imunoglobulin heavy chain dan perakitannya dengan light chain diregulasi oleh chaperones, yaitu suatu protein residen di retikulum endoplasma. Setelah proses perakitan selesai, molekul imunoglobulin akan dilepaskan dari chaperones kemudian akan ditransportasikan ke dalam cisternae komplek golgi tempat terjadi modifikasi karbohidrat, dan kemudian ke membran plasma di vesikel. Di dalam bentuk membran akan terpancang di membran plasma, sedangkan IgM dalam bentuk pentamer akan ditransportasikan ke luar sel $\begin{array}{llll}\text { (Abbas et } & \text { al., }\end{array}$ 

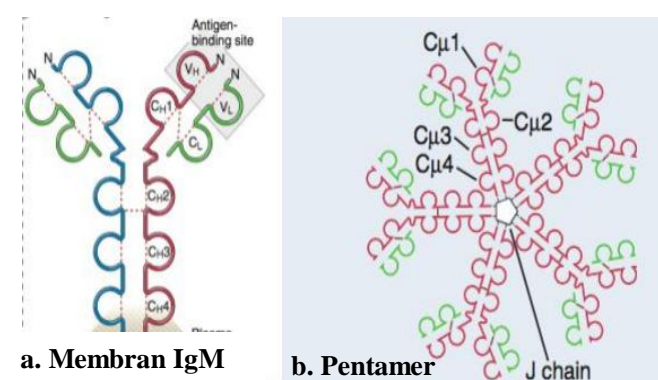

Gambar 2.3 Struktur IgM (Abbas et al., 2012)

Dalam bentuk monomer, IgM berfungsi sebagai reseptor permukaan sel yang akan mengenali antigen dan menginisiasi proses aktivasi sel B. Sel B matur mengekspresikan molekul IgM dan IgD dalam bentuk membran. Saat sel limfosit B matur diaktivasi oleh antigen dan berbagai stimulus lainnya, sel B akan berdiferensiasi menjadi sel pensekresi antibodi (antibody-secreting cell) (Abbas et al., 2012). Proses ini juga disertai dengan terjadinya perubahan pola produksi imunoglobulin. Salah satu perubahan yang muncul adalah meningkatnya produksi imunoglobulin dalam bentuk sekresi dibandingkan dalam bentuk membran. Perubahan lainnya adalah munculnya ekspresi isotype heavy chain imunoglobulin selain IgM dan IgD (Class switching). Dalam bentuk polimer, molekul IgM berperan sebagai aktivator kaskade komplemen jalur klasik yang sangat efisien, Satu molekul IgM dapat mengaktifkan komponen komplemen $\mathrm{Cl}$ sedangkan untuk fungsi yang sama dibutuhkan beberapa molekul $\operatorname{lgG}$ (Abbas et al., 2012).

2.9 imunodiagnosis demam tifoid

Rapid test: merupakan suatu alat diagnostik yang sederhana, reliable, dan relatif murah. Alat ini cocok digunakan di daerah terpencil yang memiliki keterbatasan fasilitas laboratorium dan penggunanya tidak memerlukan pelatihan khusus untuk menggunakan alat ini (Parry et al., 2011). Kelas antibodi yang dapat dideteksi oleh alat ini biasanya IgM, yang merupakan petunjuk adanya infeksi yang baru atau sedang terjadi (Parry $e t$ al., 2011) Beberapa rapid test juga dapat mendeteksi IgG yang merupakan indikasi adanya infeksi yang sedang terjadi atau paparan infeksi sebelumnya (Parry et al., 2011).

\subsection{TUBEX ${ }^{\circledR}$ TF}

Pemeriksaan Tubex merupakan pemeriksaan aglutinasi kompetitif semikuantitatif yang cepat dan mudah untuk dikerjakan. Pemeriksaan ini mendeteksi antibodi IgM terhadap antigen LPS 0-9 pada serum pasien, prinsip kerjanya dengan menggunakan metode reaksi Inhibition Magnetic Binding Immunoassay $\left(\mathrm{IMBI}^{\circledR}\right)$ yaitu dengan cara mengukur kemampuan serum antibodi IgM dalam menghambat reaksi antara antigen Salmonella enterica serovar Typhi dan anti-09 IgM monoclonal antibody (MAb). Selanjutnya ikatan inhibisi akan dipisahkan oleh suatu daya magnetik (Rahman, 2007). Penelitian Olsen (2004) yang dilakukan pada anak deman hari ke enam dibandingkan kultur didapatkan sensitivitas dan spesifisitas $78 \%$ dan $94 \%$ (Marleni, 2012; Olsen, 2004).

\subsection{Prinsip Inhibition Magnetic Binding Immunoassay (IMBI ${ }^{\circledR}$ ) \\ Uji TUBEX $T F$ menggunakan motode} Inhibition Magnetic Binding Immunoassay $\left(\mathrm{IMBI}^{\circledR}\right)$ untuk mendeteksi antibodi serum spesifik (IgM) tethadap antigen O9 yang terdapat pada lipopolisakarida (LPS) Salmonella enterica serovar Typhi (Lim et al., 1998).

Antigen $\mathrm{O} 9$ bersifat imunodominant yang dapat merangsang respon imun secara independen, antigen ini dapat langsung merangsang mitosis sel B tanpa memerlukan bantuan dari sel $\mathrm{T}$. Karena memiliki sifat ini, maka respon imun terhadap antigen $\mathrm{O} 9$ bersifat cepat, sehingga deteksi terhadap antibodi anti O9 dapat dilakukan lebih dini, yaitu pada hari ke-5 untuk indikasi primer dan hari ke-2 untuk infeksi sekunder (Widodo, 2009).

Imunoglobulin M (IgM) dapat terdeteksi adanya kemampuan untuk menghambat reaksi perlekatan antara reagen monoklonal antibodi (anti-O9 $\mathrm{mAb}$ ) berlabel lateks warna biru dengan reagen antigen $\mathrm{O} 9$ LPS Salmonella enterica serovar Typhi berlabel partikel lateks magnetik, yang mana ikatan inhibisi itu nantinya akan dipisahkan oleh suatu daya magnetik (Lim et al., 1998; Tam et al., 2008).

Komponen yang berperan pada metode IMBI ini adalah: (i) Partikel antigen O9 LPS Salmonella enterica serovar Typhi yang berlabel lateks magnetik (reagen Cokelat), (ii) Partikel anti-O9 monoklonal antibodi yang berlabel partikel latek berwarna (reagen biru), (iii) Penyangga magnet (magnetic stand) yang berfungsi untuk mengendapkan perlekatan ikatan partikel antigen-antibodi (IDL Biotech, 2008).

\subsection{Prinsip Pemeriksaaan TUBEX ${ }^{\circledR}$ TF}

Pada kondisi tidak adanya antibodi dari serum, bila suspensi cair dari kedua reagen (reagen biru dan cokelat) dicampurkan maka akan terjadi perlekatan antara reagen partikel monokonal antibodi dengan partikel antigen dan keduanya akan mengendap ke bagian dasar tabung reaksi yang berbentuk $\mathrm{V}$ saat tabung reaksi tersebut di letakkan di penyangga magnet 
Jurnal Biosains Pascasarjana Vol. 19 (2017) pp

(C) (2017) Sekolah Pascasarjana Universitas Airlangga, Indonesia (Lim et al., 1998; Tam et al., 2008). 


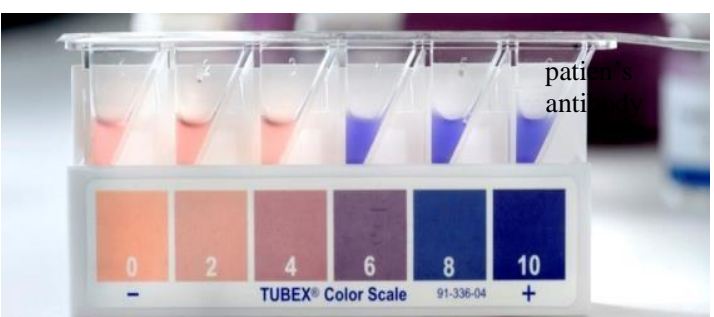

Gambar 2.5 skala warna hasil uji tubex ${ }^{\circledR}$ if (dl biotech, 2011)

Pembacaan hasil uji TUBEX $^{\circledR} \quad T F$ dilakukan setelah 5 menit proses sedimentasi partikel-partikel magnetik dengan magnet yang terdapat pada penyangga magnet (Tam et al., 2008b). Hasil (semikuantitatif) dibaca secara visual berdasarkan warna yang terlihat setelah reaksi pencampuran dilakukan dan dibandingkan dengan skala warna yang terdapat pada kit TUBEX $^{\circledR} T F$, rentang skor hasil yaitu dari 0 (warna merah, sangat negatif) megatin hingga 10 (warna biru tua, sangat positif) (Kawano et al., 2007; Tam et al., 2008a).

Di antara keuntungan dari uji TUBEX ${ }^{\circledR}$ TF adalah: (1) memiliki sensitivitas dan spesifitas yang relative tinggi, (2) menggunakan antigen O9 LPS Salmonella enterica serovar Typhi yang sangat spesifik, (3) prosedur pemeriksaan yang sangat mudah sehingga dapat dilakukan oleh teknisi tanpa pelatihan khusus, (4) dapat dilakukan dimana saja, tidak harus di dalam laboratorium, (5) dapat menguji banyak tes sekaligus sehingga dapat digunakan pada mass screening, (6) hasil dapat diperoleh secara cepat kurang lebih 10 menit, (7) sampel darah yang dibutuhkan hanya sedikit, non invasif (Lim et al., 1998; Olsen et al., 2004; Kawano et al., 2007; PT. Pacific Biotekindo Intralab, 2007; IDL Biotech, 2008).

\subsection{Typhidot-M}

Uji ini menggunakan membran nitroselulosa dengan $50-\mathrm{kDa}$ protein tertentu dan antigen kontrol (Narayanappa et al., 2010).

\subsubsection{Prinsip immunochromatographic test} (ICT)

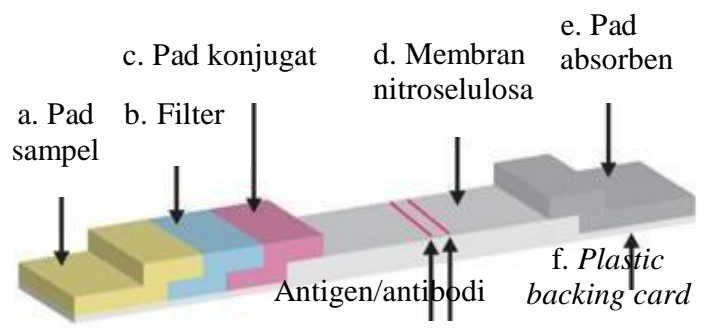

Gambar 2.7 immunochromatographic test (reszonics.com, 2011)
Sampel pasien (serum/plasma/darah utuh) diteteskan pada pad sampel (Gambar 2.8), untuk sampel whole blood, buffer diteteskan pada pad sampel setelah sampel pasien.

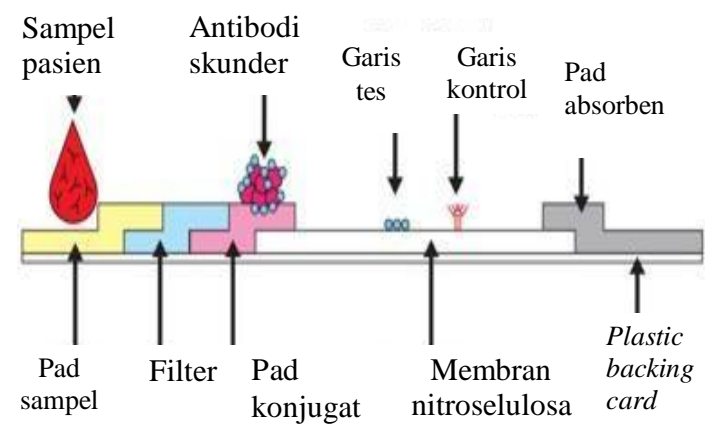

Gambar 2.8 pad sampel (reszonics.com, 2011)

Absorbent pad di ujung menyebabkan kapiler, yang sesuai sampel (dan penyangga) terhadap filter (Gambar 2.9). Ketika sampel mengalir melalui filter, sel-sel darah merah dalam sampel whole blood terdapat di filter, sedangkan serum yang mengandung antibodi pasien melewati filter menuju pad konjugat.

\subsubsection{Prinsip Pemeriksaan Typhidot-M}

Typhidot-M merupakan uji imunokromatografi fase padat tidak lansung. Antigen spesifik Salmonella typhi bergerak ke strip membran selulosa nitrat. Ketika sampel uji ditambahkan ke pad sampel, akan bermigrasi ke atas. Jika antibodi spesifik berada dalam sampel uji (serum atau plasma), akan membentuk kompleks antigen-antibodi dengan antigen bergerak di zona jendela uji. Antigen-antibodi komplek yang terikat kemudian dideteksi oleh pewarna terkonjugasi IgM goat anti human ketika chese buffer ditambahkan dan bermigrasi ke bawah, memberikan warna pink keunguan. Garis kontrol berisi rabbit anti-goat IgG yang mengikat dengan pewarna terkonjugasi goat anti human IgM. Band kontrol berfungsi sebagai indikasi migrasi yang tepat yang ditambah dengan reagen kontrol.

\subsubsection{Interpretasi Hasil Typhidot-M}

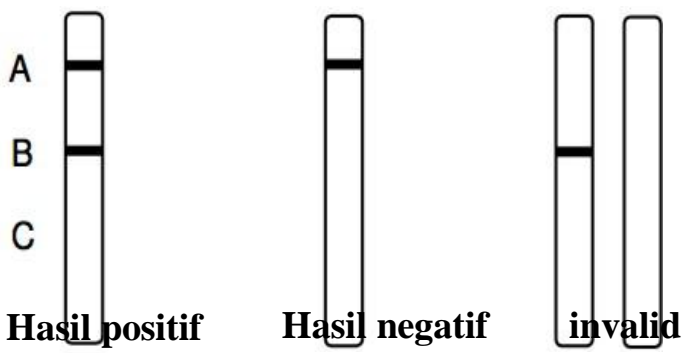

Gambar 2.12 Interpretasi Hasil Typhidot-M (reszonics.com, 2011) 
Hasil pemeriksaan Typhidot-M sebagai berikut: 1). Hasil positif untuk antibodi spesifik Salmonella typhi: Warna tebal muncul di garis kontrol (A) dan garis Tes (B), 2). Hasil negatif untuk antibodi spesifik Salmonella typhi: Hanya garis kontrol (A) yang terlihat, 3). Hasil tidak valid: Garis kontrol (A) tidak ada. Jika hal ini terjadi, pengujian harus diulang menggunakan kaset pengujian baru.

\section{METODE PENELITIAN}

Penelitian ini menggunakan Deskriptif dengan pendekatan Observasional, Teknik pengambilan sampel dilakukan dengan cara purposive sampling, yaitu mengambil pengambilan sampel yang di dilai sesuai tujuan peneliti dan sesuai dengan ciri atau sifat tertentu yang sudah diketahui sebelumnya

\section{HASIL DAN PEMBAHASAN}

Penelitian ini dilakukan pada bulan Januari 2017 sampai dengan Mei 2017, Sampel dikumpulkan sebanyak 38 sampel serum yang berasal dari pasien dengan gejala klinik demam tifoid berdasarkan skor Nelwan $(\geq 8)$ dan data lain diantaranya: jenis kelamin, usia, Suhu tubuh disajikan dalam bentuk Tabel distribusi frekuensi dan persentase.

Pemeriksaan IgM anti-Salmonella enterica Serovar Typhi pada serum pasien dengan metode Inhibition Magnetic Binding Immunoassay $\left(\mathrm{IMBI}^{\circledR}\right)$ pada Kit TUBEX TF. Hasil pemeriksaan berdasarkan skor 0 sampai dengan 10 , dinyatakan postif jika skor $\left(\geq_{4}\right)$ dan dinyatakan negatif jika hasil skor $(<4)$. Selain itu serum pasien dipemeriksa menggunakan Kit Typhidot-M (Reszon Diagnostics International Sdn. Bhd). Hasil dinyatakan positif jika terdapat 2 garis antara garis $\mathrm{A}$ dan $\mathrm{B}$, dinyatakan hasil negatif jika hanya terdapat 1 garis pada garis $\mathrm{A}$.

Pada penelitian ini sampel yang digunakan sebanyak 38 sampel serum yang berasal dari pasien laki-laki sebanyak 20 sampel serum dan perempuan sebanyak 20 sampel seum yang memenuhi kreterian skor Nelwan $(\geq 8)$, dari hasil analisis deskriptif menunjukkan hasil sebagai berikut: Skor minimal 8, skor maksimal 16 dengan skor rata-rata 11.4211 dan standar devisiasi 3.30136. Usia terbanyak 13 sampai dengan 24 tahun sebanyak 17 sampel, 14 sampel yang memiliki usia 1 tahun sampai dengan 12 tahun dan tidak terdapat pasien yang memiliki rentan usia 37 tahun sampai dengan 60 tahun. Hasil deskriptif berdasarkan usia kejadian demam tifoid ssesuai dengan hasil penelitian yang dilakukan oleh penelitian lain dengan usia rata-rata kejadian demam tifoid lebih banyak pada usia 24 tahun (Karen., 2011; WHO., 2017). Terdapatnya persamaan hasil yang didapat dikarena pada umumnya, demam tifoid menyerang penderita usia 5-30 tahun, tetapi kasus ini juga ditemukan pada anak usia di bawah 2 tahun (Lin et al., 2000; Nasronuddin, 2007; Zaki et al., 2011), selain itu kemungkinan terdapat berbagai macam faktor yang mempengaruhi kejadian demam tifoid pada pasien usia 1 tahun sampai dengan 12 tahun maupun usia 13 tahun sampai dengan 24 tahun, diantaranya: kurangnya kebersihan individu, lingkungan tempat tinggal yang sangat padat, persediaan air bersih yang belum mencukupi, menurunnya system imun penderita, adanya mutasi genetik bakteri Salmonella enterica Serovar Typhi dan munculnya multidrug resistant (Kumar et al., 2007; Nasronuddin, 2007; Kothari et al., 2008; Zaki et al., 2011).

Tabel 4.1 Hasil analisis deskriptif suhu tubuh

\begin{tabular}{lcl}
\hline Hasil & TUBEX TF & Typhidot-M \\
\hline Positif & 25 & 23 \\
Negatif & 13 & 15 \\
Total & 38 & 38 \\
\hline
\end{tabular}

Perbedaan hasil interpretasi antara kit TUBEX TF dan kit Typhidot-M pada pemeriksaan IgM anti-Salmonella enterica Serovar Typhi. Pada Tabel 5.7 hasil deteksi tidak dilakukan analisis statistik, karena pneliti hanya bertujuan untuk mengidentifikasi hasil positif maupun negatif dari masing-masing kit, dimana antara kedua hasil kit menunjukkan hasil deteksi positif dari TUBEX TF sebanyak 25 sampel dan hasil negatif sebanyak 13 sampel, hasil dari pemeriksaan Typhidot-M menunjukkan hasil postif sebanyak 23 sampel dan hasil negatif sebanyak 15 sampel. Dari hasil pemeriksaan TUBEX TF dan Typhidot-M berdasarkan frekuensinya bahwa kit TUBEX TF lebih banyak memiliki hasil deteksi positif dibandingkan dengan hasil positif yang dimiliki kit Typhidot-M pada sampel serum pasien yang sama dengan selisih hasil positif sebanyak 2 sampel. Adanya selisih hasil pemeriksaan tersebut maka dapat dinyatakan bahwa ada perbedaan hasil deteksi antra kit TUBEX TF dengan kit Typhidot-M dalam deteksi IgM antiS.Thypi pada pasien demam tifoid yang memenuhi kreteria skor Nelwan. 
Tabel 4.2 hasil tabulasi silang tubex if dengan typhidot-m

\begin{tabular}{|c|c|c|c|c|}
\hline & & \multicolumn{3}{|c|}{ Typhidot-M } \\
\hline & & Positif & Negati & Total \\
\hline TUBEX & Positif & 23 & 2 & $25 /$ \\
\hline$T F$ & Negatif & 0 & 13 & 13 \\
\hline Total & & 23 & 15 & 38 \\
\hline
\end{tabular}

Nilai $\boldsymbol{P}=0.000<0.05$

Tingkat kesesuaian hasil deteksi IgM antiSalmonella enterica Serovar Typhi kit TUBEX TF dengan kit Typhidot-M, Berdasarkan Tabel 4.2 Menunjukkan 23 sampel $(60.5 \%)$ positif pada kit TUBEX TF maupun kit Typhidot-M, 2 sampel (5.3\%) positif pada kit TUBEX TF tetapi negatif pada ki Typhidot-M dalam mendeteksi IgM anti-Salmonella enterica Serovar Typhi, 0 sampel $(0 \%)$ hasil negatif pada kit TUBEX TF tetapi 13 sampel (34.2\%) negatif pada kit Typhidot-M dalam mendeteksi IgM anti-Salmonella enterica Serovar Typhi. Hasil analisis Chi-Square terdapat nilai $\rho=0.000<$ 0.05 yang menunjukkan bahwa terdapat hubungan yang bermakna (significant) antara hasil deteksi kit TUBEX TF dengan hasil deteksi kit Typhidot-M pada pemeriksaan IgM anti-Salmonella enterica Serovar Typhi dan nilai kappa: 0.887 yang berarti terdapat tingkat kesesuaian yang sangat baik antara hasil kit TUBEX TF dengan kit Typhidot-M pada pemeriksaan IgM anti-Salmonella enterica

Serovar Typhi. Kreteria nilai kappa yang digunakan sebagai berikut bila kappa $(>0,75)$ menunjukkan tingkat kesesuaian sangat baik, 0,4-0,75 menunjukkan tingkat kesesuaian yang baik dan $(<0,4)$ menunjukkan tingkat kesesuaian yang buruk (Dahlan, 2010). berdasarkan Tabel 5.7 dapat dihitung nilai sensitivitas $100 \%$ $(23 / 23+0)$ dan spesifisitas sebesar $86,7 \%$ $(13 / 13+2)$, nilai prediktif positif $92 \%(23 / 23+2)$ dan nilai prediktif negatif $100 \%(13 / 13+0)$. Hasil dari penelitian ini memiliki sensitifitas dan spesifisitas lebih tinggi dari penelitian sebelumnya yang menggunakan 3 uji serologi sekaligus, didapatkan pemeriksaan TUBEX TF memiliki sensitifitas dan spesifisitas tinggi (78\% dan $89 \%$ ) jika dibandingkan pemeriksaant carik celup Multi-test Dip-S-Ticks (89\% dan 53\%), Typhidot (79 dan 89\%), serta Widal (64 dan 76\%) (Olsen et al., 2004). Typhidot dan pemeriksaan TUUBEX TF menunjukkan hasil yang tidak berbeda jauh, namun jika dipertimbangkan dari segi biaya dan teknik pemeriksaannya, pemeriksaan TUUBEX TF lebih unggul dengan biaya relatif lebih murah dan prosedur yang sederhana (Bibb et al., 2004). Namun hasil peneliti saat ini berbeda dengan hasil yang pernah dilakukan oleh peneliti lain di afrika utara dan repoblik Tanzania dimana sensitivitas kit Typhidot-M (75\%) lebih tinggi dibandingkan dengan sensitivitas kit TUBEX if $(15 \%)$ dengan kultur aaran sebagal gold standard (Keddv et al.. 2011). Hasil anatara kit TUBEX TF dan kit Typhidot-M yang memiliki sensitifitas dan spesifisitas lebih tinggi dari peneliti sebelumnya. Beberapa laporan menunjukkan bahwa tes Typhidot-M mungkin lebih bermanfaat di Asia (Keddy et al., 2011). Adanya kemungkinan disebabkan adanya perbedaan serotype/serovar dari masing-masing negaragara sehingga mengakibatkan tingkat sensitifitas maupun spesifitas dari kit yang digunakan sebagai diagnosis cepat dalam mendeteksi IgM memiliki hasil yang berda, peneliti saat ini tidak menggunakan pemeriksaan biakan darah dari sumsum tulang atau menggunakan kultur darah sebagai baku emas. Peneliti saat ini hanya menggunakan skor Nelwan sebagai kreteria penentu adanya demam pada sampel yang diteliti, sehingga besar kemungkinan untuk terjadinya subjektifitas dari peneliti. Mengingat demam tifoid tidak ada gejala klinis yang tunggal untuk mengetahui pasti atau tidak terjadinya demam tifoid yang terjadi pada pasien yang dijadikan sampel penelitian saat ini.

Tabel 4.3 hasil tabulasi silang suhu tubuh dengan kit tubex if

\begin{tabular}{|c|c|c|c|c|}
\hline & \multicolumn{3}{|c|}{ TUBEX $T F$} \\
\hline & & Psitif & Negatif & Total \\
\hline \multirow{2}{*}{$\begin{array}{l}\text { Suhu } \\
\text { Tubuh }\end{array}$} & $>37.5^{\circ} \mathrm{C}$ & 19 & 4 & 23 \\
\hline & $<37.5^{\circ} \mathrm{C}$ & 6 & 9 & 15 \\
\hline \multicolumn{2}{|l|}{ Total } & 25 & 13 & 38 \\
\hline \multicolumn{5}{|c|}{ Nilaip:0.013 < 0.05} \\
\hline
\end{tabular}

Suhu tubuh merupakn salah satu gejala sistemik demam tifoid sehingga penilti saat ini ingin mengetahui bagaimana hubungan antara hasil deteksi IgM dari kit TUBEX TF maupun kit Typhidot-M terhadap suhu tubuh sebagai upaya deteksi dini dari demam tifoid. Pada penelinian saat ini hubungan suhu tubuh dengan hasil interpretasi deteksi IgM anti-Salmonella enterica Serovar Typhi dengan kit Typhidot-M, berdasarkan Tabel 4.3 terdapat 19 sampel (50\%) positif, 4 sampel $(10.5 \%)$ negatif yang berasal dari pasien demam tifoid dengan suhu tubuh 
Jurnal Biosains Pascasarjana Vol. 19 (2017) pp

(C) (2017) Sekolah Pascasarjana Universitas Airlangga, Indonesia $>37.50 \mathrm{C}$ pada pemeriksaan IgM dengan kit 
TUBEX TF dan terdapat 6 sampel (15.8\%) postif, 9 sampel $(23.6 \%)$ negatif yang berasal dari pasien demam tifoid dengan suhu tubuh $<37.50 \mathrm{C}$ pada pemeriksaan IgM dengan kit TUBEX TF. Hasil analisis Chi-Square didapat nilai $\rho=0.013<0.05$ yang menunujuk terdapat hubungan yang bermakna (significant) antara suhu tubuh dengan hasil deteksi kit TUBEX TF dan nilai kappa $=0.436$ yang berarti tingkat hubungan yang baik pada pemeriksaan IgM anti-Salmonella enterica Serovar Typhi.

Tabel 4.4 hasil tabulasi silang suhu tubuh dengan typhidot-m

\begin{tabular}{|c|c|c|c|c|}
\hline & & \multicolumn{3}{|c|}{ Typhidot-M } \\
\hline & & Positif & Negatif & Total \\
\hline \multirow{2}{*}{$\begin{array}{l}\text { Suhu } \\
\text { tubuh }\end{array}$} & $>37.5^{\circ} \mathrm{C}$ & 17 & 6 & 23 \\
\hline & $<37.5^{\circ} \mathrm{C}$ & 6 & 9 & 15 \\
\hline Total & & 23 & 15 & 38 \\
\hline \multicolumn{5}{|c|}{ Nilai $\rho=0.049<0.05$} \\
\hline
\end{tabular}

Berdasarkan Tabel 5.10 terdapat 17 sampel (44.7\%) positif, 6 sampel $(15.8 \%)$ negatif yang berasal dari pasien demam tifoid dengan suhu tubuh $>37.5^{\circ} \mathrm{C}$ pada pemeriksaan IgM dengan kit Typhidot-M dan terdapat 6 sampel (15.8\%) postif, 9 sampel (23.6\%) negatif yang berasal dari pasien demam tifoid dengan suhu tubuh $<37.50 \mathrm{C}$ pada pemeriksaan IgM dengan kit Typhidot-M. Hasil analisis Chi-Square didapat nilai $\rho=0.049<0.05$ yang menunjukkan terdapat hubungan antara suhu tubuh dengan dengan hasil deteksi Typhidot-M dan nilai kappa $=0.339$ yang berarti tingkat hubungan yang buruk pada pemeriksaan IgM antiSalmonella enterica Serovar Typhi dengan kit Typhidot-M. Hasil Studi yang dilakukan di Tanzania menggunakan suhu $>38^{\circ} \mathrm{C}$ (riwayat demam atau menunjukkan pireksia) sebagai kreteria inklusi untuk melakukan evaluasi kit Typhidot-M yang dibandingkan dengan hasil kultur darah menunjukkah hasil hubungan antara kit diagnosis cepat pada demam tifoid buruk (keddy et al., 2011), akan tetapi hasil pemeriksaan IgM dengan Kit TUBEX TF berbeda, dimana hasil penelitian yang dilakukan oleh peneliti saat ini menunjukan hasil yang baik.

Kreteria suhu tubuh normal bila berkisar antara $36^{\circ} \mathrm{C}$ sampai dengan $37,5^{\circ} \mathrm{C}$, demam bila suhu tubuh antara $37,6^{\circ} \mathrm{C}$ sampai dengan $40^{\circ} \mathrm{C}$ yang dinyatakan (Tamsuri, 2007). International Union of Physiological Sciences Commission for Thermal Physiology yang mendefinisikan bahwa demam/febris sebagai suatu keadaan peningkatan suhu inti, yang sering merupakan bagian dari respons pertahanan organisme multiselular host terhadap invasi mikroorganisme atau benda mati yang patogenik atau dianggap asing oleh host. ElRahdi dkk., mendefinisikan demam (pireksia) dari segi patofisiologis dan klinis. Secara patofisiologis demam adalah peningkatan thermoregulatory set point dari pusat hipotalamus yang diperantarai oleh interleukin 1 (IL-1). Sedangkan secara klinis demam adalah peningkatan suhu tubuh $1 \mathrm{oC}$ atau lebih besar di atas nilai rerata suhu normal di tempat pencatatan. Sebagai respons terhadap perubahan set point ini, terjadi proses aktif untuk mencapai set point yang baru. Hal ini dicapai secara fisiologis dengan meminimalkan pelepasan panas dan memproduksi panas (ElRadhi, 2009; Fisher RG, 2005).

Terjadinya hasil positif yang dominan pada kit TUBEX TF dan Typhidot-M kemungkinan disebabkan oleh faktor seperti faktor individu dan lingkungan, meliputi usia, jenis kelamin, aktivitas fisik dan suhu udara ambien dan kemungkinan tempat pengukuran yang berbeda dari masing-masing sampel sehingga perlu adanya pengelompokan yang lebih spesifik untuk mengethui seberapa besar hubungan antara suhu tubuh dengan kejjadian demam tifoid berdasarkana tempat pengukuran suhu maupun waktu pengukuran suhu tubuh.

Disamping itu pirogen berinteraksi dengan sel fagosit, makrofag atau monosit, untuk merangsang sintesis IL-1. Mekanisme lain yang mungkin berperan sebagai pirogen eksogen (misalnya endotoksin) bekerja langsung pada hipotalamus untuk mengubah pengatur suhu. Pirogenitas bakteri Gram-negatif (misalnya Escherichi coli, Salmonela) disebabkan adanya lzeat-stable factor yaitu endoktosin, suatu pirogen eksogen yang pertama kali ditemukan. Komponen aktif endotoksin berupa lapisan luar bakteri yaitu lipopolisakarida (Soedarmo et al., 2008). Kit TUBEX TF menggunakan motode Inhibition Magnetic Binding Immunoassay (IMBI囚) untuk mendeteksi antibodi serum spesifik (IgM) tethadap antigen $\mathrm{O} 9$ yang terdapat pada lipopolisakarida (LPS) Salmonella enterica Serovar Typhi sehigga kit TUBEX TF lebih banyak mendeteksi IgM. Imunoglobulin $\mathrm{M}$ muncul pada minggu pertama dan diikuti peningkatan suhu tubuh pasien demam tifoid sehingga hasil positif sampel serum dari pasien yang memiliki suhu $\geq 37.60 \mathrm{C}$ lebih dominan. 
Sedangkan kit Typhidot-M mendeteksi IgM anti-Salmonella enterica Serovar Typhi menggunakan Outer Membrane Protein (OMP) resisten pada suhu $800 \mathrm{C}$ sampai dengan $1000 \mathrm{C}$ meskipun demikian ada kemungkinan terjadinya perubahan yang dipengaruhi oleh suhu lingkungan maupun pada pasien itu sendiri sehingga terdeteksinya hasil negatif pada pemeriksaan IgM pada seum pasien demam tifoid.

\section{KESIMPULAN DAN SARAN}

Berdasarkan hasil penelitian yang di dapat, maka dapat ditarik kesimpulan sebagai berikut: Terdapat perbedaan hasil interpretasi antara pemeriksaan TUBEX $^{\circledR} T F$ dan Typhidot-M anti-Salmonella enterica Serovar Typhi pada serum pasien demam tifoid di RSUD Dr. Soetomo Surabaya.

Tingkat kesesuaian hasil pemeriksaan TUBEX TF dan Typhidot-M anti-Salmonella enterica Serovar Typhi pada serum pasien demam tifoid di RSUD Dr. Soetomo surabya, Analisis Chi-Square terdapat nilai $\rho=0.000<$ 0.05 yang menunjukkan bahwa terdapat hubungan yang bermakna (significant) antara hasil deteksi kit TUBEX $T F$ dengan hasil deteksi kit Typhidot-M pada pemeriksaan IgM anti Salmonella enterica Serovar Typhi dan nilai kappa $=0.887$ yang berarti terdapat tingkat kesesuaian yang sangat baik antara hasil kit TUBEX $T F$ dengan kit Typhidot-M pada pemeriksaan $\mathrm{IgM}$ anti-Salmonella enterica Serovar Typhi.

Terdapat hubungan suhu tubuh dengan hasil pemeriksaan TUBEX ${ }^{\circledR} T F$ dalam deteksi anti-Salmonella enterica Serovar Typhi pada serum pasien demam tifoid di RSUD Dr. Soetomo surabya dengan nilai $\rho=0.013<0.05$ dan nilai kappa $=0.436$ yang berarti tingkat hubungan yang baik pada pemeriksaan IgM anti-Salmonella enterica Serovar Typhi.

Terdapat hubungan suhu tubuh terhadap hasil pemeriksaan Thipidot-M dalam deteksi anti-Salmonella enterica Serovar Typhi pada serum pasien demam tifoid di RSUD Dr.

Soetomo surabya dengan nilai $\rho=0.049<0.05$ dan nilai kappa $=0.339$ yang berarti tingkat hubungan yang buruk pada pemeriksaan IgM anti-Salmonella enterica Serovar Typhi dengan kit Typhidot-M.

Berdasarkan hasil penelitian ini maka disarankan penggunaan kit Typhidot-M dapat digunakan sebagai diagnosis cepat bila kit TUBEX TF tidak tersedia.

Untuk peneliti selanjutnya disarankan untuk membandingkan hasil TUBEX TF dan Typhodot-M menggunakan kultur darah sebagai gold standar dalam deteksi IgM anti-Salmonella enterica Serovar Typhi (S. typhi).

\section{UCAPAN TERIMA KASIH}

Ucapan terimakasih yang tak terhingga dan penghargaan yang setinggi- tingginya, saya ucapkan kepada Bapak Prof. Dr. Jusak Nugraha, dr., MS., Sp.PK (K), Sebagai pembimbing ketua ,Ucapan terimakasih kepada Ibu Dr. Marijam Purwanta, Dra., M.Sc., Apt, SEBAGAI pembimbing II.

\section{DAFTAR PUSTAKA}

Abbas AK, Andrew H, and Pillai S. 2012. Immunity To Mikrobes. In Cellular And Molecular Immunology. 7th Edition, Philadelphia; WB Elsiver Company.

Achtman, M.; Wain, J.; Weill, F. O. X.; Nair, S.; Zhou, Z.; Sangal, V.; Krauland, M. G.; Hale, J. L.; Harbottle, H.; Uesbeck, A.; Dougan, G.; Harrison, L. H.; Brisse, S.; .2012. S. Enterica MLST Study Group. Bessen, Debra E, ed. "Multilocus Sequence Typing As A Replacement For Serotyping In Salmonella Enterica". PLOS Pathogens. 8 (6): e1002776. doi:10.1371/journal.ppat.1002776. PMC 3380943 . PMID 22737074

Bib W, Minh NT, Olsen SJ, Pruckler J, Thanh NTM, Trinh TM, et al. 2004. "Evaluation Of Rapid Diagnostic Tests For Typhoid Fever". Journal of Clinical Microbiology. 42(5). 1885- 9.

Brenner, Villar, R.G, Angulo, F. J.;Tauxe, R. And B. Swaminathan. 2000. Salmonella Nomenclature. Journal of Clinical Microbiology, p. 2465-2467 0095$1137 / 00 / \$ 04.000$

Crump, J.A. and Mintz, E.D. 2010. Global Trends In Typhoid And Paratyphoid Fever. Clin Infect Dis 50(2):241-246.

Crump, J.A., Luby, S.P. and Mintz, E.D. 2004. The Global Burden Of Typhoid Fever. Bull World Health Organ 82(5):461-465.

Diepen AV, Gevel JSV, Koudijs MM, Ossendrop F, Beekhuizen H, Janssen R, Dissel JTV. 2005. Gamma irradiation or CD4+ $T$ Cell Depletion Causes Reactivation of Latent Salmonella Enterica Serovar Typhimurium Infection 
In C3H/Hen Mice. Journal Infection and Immunity 75(3): 2857-2862

El-Radhi AS, Carroll J, Klein N, Abbas A. Fever. Dalam: El-Radhi SA, Carroll J, Klein N, penyunting. Clinical Manual Of Fever In Children. Edisi ke-9. Berlin: SpringerVerlag; 2009.h.1-24.

Fisher RG, Boyce TG. Fever And Shock Syndrome. Dalam: Fisher RG, Boyce TG, penyunting. Moffet's Pediatric infectious diseases: A problem-oriented approach. Edisi ke-4. New York: Lippincott William \& Wilkins; 2005.h.318-73.

Holt, et al. 1994. Bergey's Manual of Determinative Bacteriology 9th Edition. USA: Williams and Wilkins Baltimore.

Holt, K.E., Thomson, N.R., Wain, J., Langridge, G.C., Hasan, R., Bhutta, Z.A., Quail, M.A., Norbertczak, H., Walker, D., Simmonds, M. et al. 2009. Pseudogene Accumulation In The Evolutionary Histories Of Salmonella Enterica Serovars Paratyphi A And Typhi. BMC Genomics 10(36).

Hornick, R.B., Greisman, S.E., Woodward, T.E., DuPont, H.L., Dawkins, A.T. and Snyder, M.J. 1970. Typhoid Fever: Pathogenesis and Immunologic Control. N Engl J Med 283:686-691.

House, D., Wain, J., Ho, V.A., Diep, T.S., Chinh, N.T., Bay, P.V., Vinh, H., Duc, M., Parry, C.M., Dougan, G. et al. . 2001. Serology Of Typhoid Fever In An Area Of Endemicity And Its Relevance To Diagnosis. J Clin Microbiol 39(3):10021007.

IDL Biotech. 2008. Tubex-TF, Confidence In Typhoid Fever Diagnosis. Sweden.

IDL Biotech. 2011. Tubex-TF, Confidence In Typhoid Fever Diagnosis. Sweden. Jawetz, E., Melnick, J.L. and Adelberg, E.A. 1996. Mikrobiologi Kedokteran. Jakarta: EGC.

Kalbemed.com. 2014. Terapi Terkini Demam Tifoid. diakses 23 november 2016.

Kaur, J. and Jain, S.K. 2012. Role Of Antigens And Virulence Factors of Salmonella Enterica Serovar Typhi In Its Pathogenesis. Microbiological Research 167:199-210.

Kawano, R.L., Leano, S.A. and A, D.M. 2007. Comparison Of Serological Test Kits For Diagnosis Of Typhoid Fever In The Philippines. Journal of clinical microbiology 45:246-248.
Keddy, Arvinda S., Maupi E., Greta H., Claire LC., Anne M \& John A. 2011. Sensitivity And Speci City Of Typhoid Fever Rapid Antibody Tests For Laboratory Diagnosis At Two Sub-Saharan African Sites. Bull World Health Organ;89:640-647 doi:10.2471/BLT.11.087627

Kothari, A., Pruthi, A. and Chugh, T.D. 2008. The Burden of Enteric Fever. J Infect Dev Ctries 28:253-259.

Kumar, R., Gupta, N. and Shalini. 2007. Multidrug-Resistant Typhoid Fever. Indian J Pediatr 74:39-42.

Marleni, M. 2012. Ketepatan Uji Tubex TF Dibandingkan Nested-PCR Dalam Mendiagnosis Demam Tifoid Pada Anak Pada Demam Hari Ke-4. Universitas Sriwijaya. Palembang.

McClelland, M., Sanderson, K.E., Clifton, S.W., Latreille, P., Porwollik, S., Sabo, A., Meyer, R., Bieri, T., Ozersky, P., McLellan, M. et al. . 2004. Comparison Of Genome Degradation In Paratyphi A And Typhi, Human- Restricted Serovars Of Salmonella Enterica That Cause Typhoid. Nature Genetics 36:1268-1274.

McSorley, S.J. and Jenkins, M.K. 2000. Antibody Is Required For Protection Against Virulent But Not Attenuated Salmonella Enterica serovar Typhimurium. Infect Immun 68(6):3344-3348.

Merieux, F. 2007. Report Of The Meeting On Typhoid Fever, A Neglected Disease: Towards a Vaccine Introduction Policy. France: Les Pensieres.

Mweu, E. and English, M. 2008. Typhoid Fever In Children In Africa. Trop Med Int Health 13(4):532-540.

Narayanappa, D, Rachana Sripathi, K Jagdishkumar And Hs Rajani. 2009. Comparative Study of Dot Enzyme Immunoassay (Typhidot-M) and Widal Test in the Diagnosis of Typhoid Fever. Department of Pediatrics, JSS Medical College, JSS University, Mysore, India.Vol 47_April 17, 2010.

Nasronuddin. 2007. Demam Tifoid. In: Nasronuddin, Hadi U, Vitanata, Erwin AT, Bramantono, Suharto, and Soeandojo E, editors. Penyakit Infeksi di Indonesia, Solusi kini dan mendatang. Surabaya: Airlangga University Press. P 121-125

Nelwan, R.H.H. 2007. Demam: Tipe dan Pendekatan dalam Sudoyo, Aru W. et.al. Buku Ajar Ilmu Penyakit Dalam Jilid III 
Edisi IV. Jakarta: Pusat Penerbitan Departemen Ilmu Penyakit Dalam FKUI.

Olsen, S.J. 2004. Evaluation of Rapid Diagnostic Test for Typhoid Fever. Journal of Clinical Microbiology.1885-1889, Vol. 42, No. 5.

Parry, C.M., Wijedoru, L., Arjyal, A. and Baker, S. 2011. The utility of diagnostic tests for enteric fever in endemic locations. Expert Rev Anti Infect Ther 9:711-725.

PT. Pacific Biotekindo Intralab. 2007. Tubex TF.

http://wwwpacbiotekindocoid/products/tu bextfphp

Pui CF, Wong WC, Chai LC, Tunung R, Jeyaletchumi P, Hidayah N, Ubong A, Farinazleen MG, Cheah YK, Shon R. 2011. Salmonella: a foodborne pathogen. Review Article International Food Research Journal. 18: 465-473.

Rahman, M., Siddique, A.K., Tam, F.C.-H., Sharmin, S., Rashid, H., Iqbal, A., Ahmed, S., Nair, G.B., Chaignat, C.-L. and Lim, P.-L. 2007. Rapid detection of early typhoid fever in endemic community children by the TUBEX® O9-antibody test. Diagnostic Microbiology \& Infectious Disease 58:275-281.

Reszon Diagnostics International Sdn. Bhd.2011. Dot EIA test for specific detection of IgG \& IgM to Salmonella typhi. Malaysian.

Roumagnac, P., Weill, F.-X., Dolecek, C., Baker, S., Brisse, S., Chinh, N.T., Le, T.A.H., Acosta, C.J., Farrar, J., Dougan, G. et al. . 2006. Evolutionary History of Salmonella Typhi. Science 314(5803): 1301-1304.

Santos S.A, Andrade Jr., D.R. and Andrade, D.R. 2011. TNF- $\alpha$ production and apoptosis in hepatocytes after Listeria monocytogenes and Salmonella Typhimurium invasion. Rev Inst Med Trop Sao Paulo 53(2):107112.

Soedarmo; Herry; Sri; Hindar.2008. Buku Ajar lnfeksi \& Pediatri Tropis. Edisi II. Badan Penerbit IDAI, Jakarta. ISBN: 979-842114-0.

Tamsuri A. 2007. Konsep Dan Penatalaksanaan Nyeri. Penerbit Buku Kedokteran EGC Jakarta.

Widodo, D. 2009. Demam tifoid. In: Sudoyo AW, Setiyohadi B, Alwi I, Simadibrata M, and Setiati S, editors. Buku Ajar Ilmu Penyakit Dalam. V ed. Jakarta: InternaPublishing.
Word Health Organization. 2014. immunization. vaccine and biologicals. Geneva: WHO. diakses 14 september 2016.

World Health Organization. 2003. Background document: The diagnosis, treatment and prevention of typhoid fever. Geneva: Communicable Disease Surveillance and Response Vaccines and Biologicals. WHO.

\section{APPENDIX}
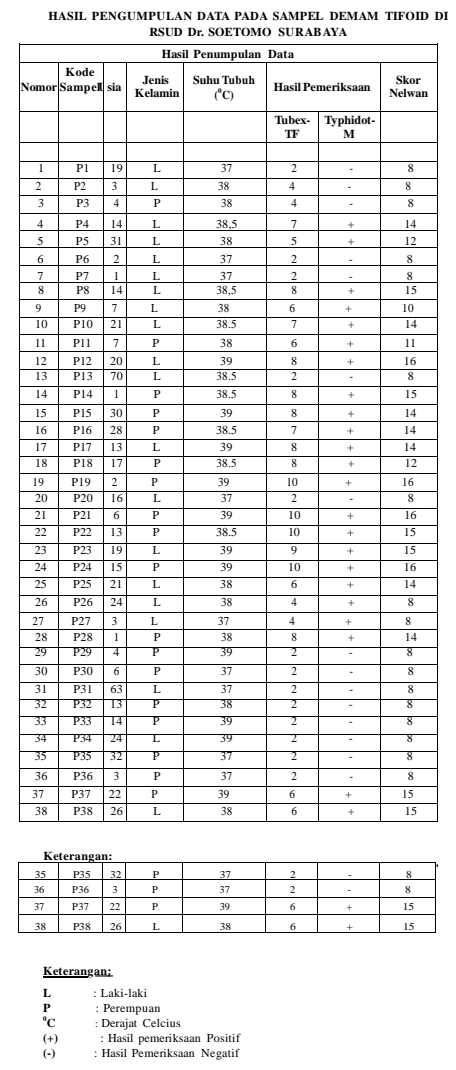
Jurnal Biosains Pascasarjana Vol. 19 (2017) pp

(C) (2017) Sekolah Pascasariana Universitas Airlangga, Indonesia
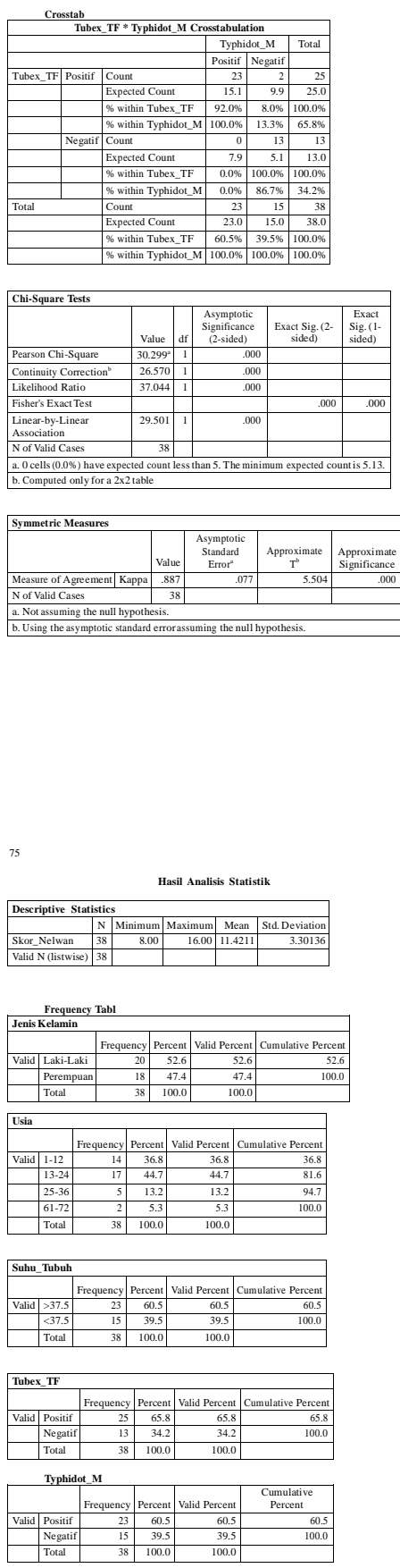

Crosstabs

Suhu_Tubuh ? Tubee__TF
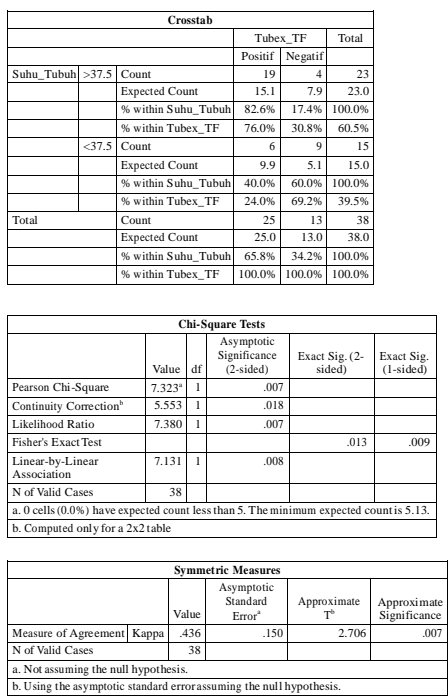

shu_Tubuh * Typhidot_.N
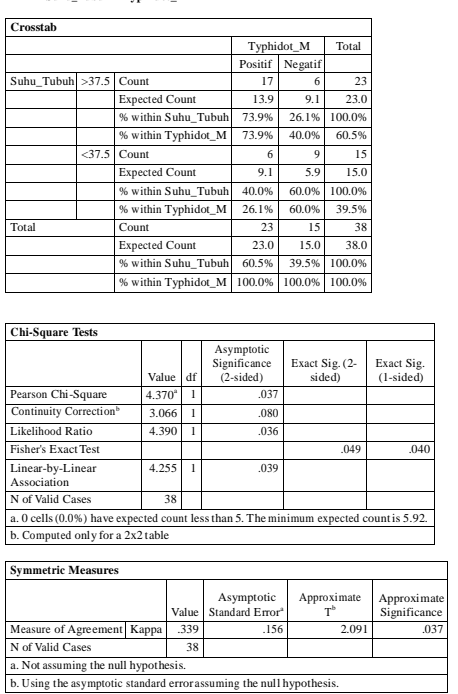
Jurnal Biosains Pascasarjana Vol. 19 (2017) pp

(C) (2017) Sekolah Pascasarjana Universitas Airlangga, Indonesia

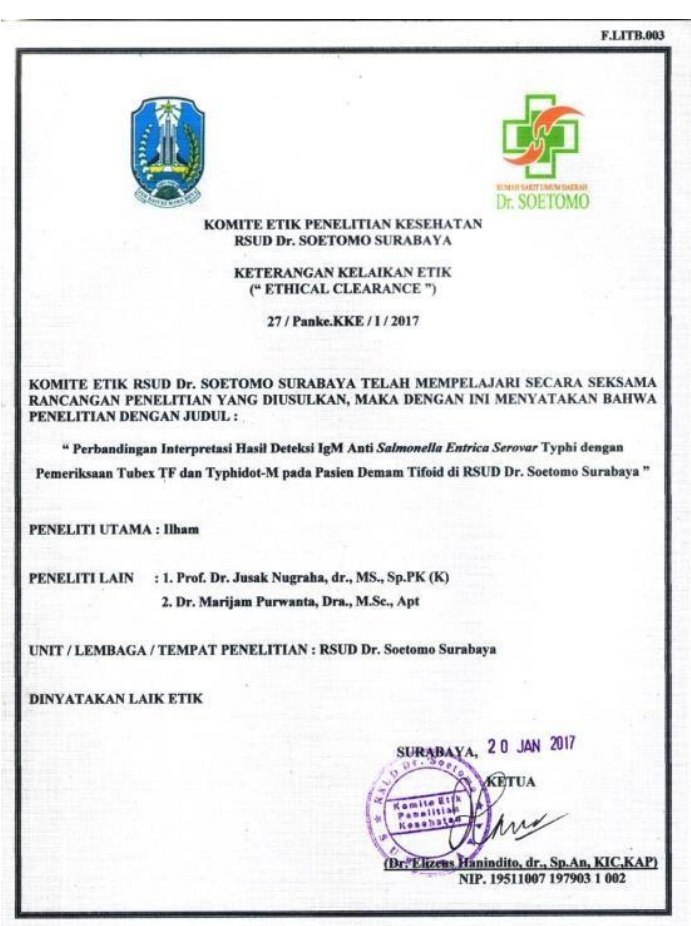

JBP Vol. 19, No. 2, Agustus 2017 - Ilham 